\title{
Corrigendum
}

\section{Corrigendum to "Effect of Selenium-Enriched Garlic Oil against Cytotoxicity Induced by OX-LDL in Endothelial Cells"}

\author{
Evidence-Based Complementary and Alternative Medicine
}

Correspondence should be addressed to Evidence-Based Complementary and Alternative Medicine; ecam@hindawi.com

Received 4 June 2020; Accepted 5 June 2020; Published 24 June 2020

Copyright ( 2020 Evidence-Based Complementary and Alternative Medicine. This is an open access article distributed under the Creative Commons Attribution License, which permits unrestricted use, distribution, and reproduction in any medium, provided the original work is properly cited.

In the article titled "Effect of Selenium-Enriched Garlic Oil against Cytotoxicity Induced by OX-LDL in Endothelial Cells" [1], the ECV-304 cell line has been found to be crosscontaminated by $\mathrm{T}-24$, which is a bladder carcinoma cell line and not of human umbilical vein endothelial cell (HUVEC) origin $[2,3]$. Hence, it is not an appropriate cell line to study endothelial cell biology.

The authors said they asked a local hospital for HUVECs and could not find in their records whether or not the type provided was indeed ECV-304 cells.

\section{References}

[1] C. Yang, K. Cui, Y. Diao, M. Du, and S. Wang, "Effect of selenium-enriched garlic oil against cytotoxicity induced by OX-LDL in endothelial cells," Evidence-Based Complementary and Alternative Medicine, vol. 2014, Article ID 537652, 6 pages, 2014.

[2] ICLAC Register of Misidentified Cell Lines, http://iclac.org/ databases/cross-contaminations/.

[3] A. Capes-Davis, G. Theodosopoulos, I. Atkin et al., "Check your cultures! A list of cross-contaminated or misidentified cell lines," International Journal of Cancer, vol. 127, no. 1, pp. 1-8, 2010. 